
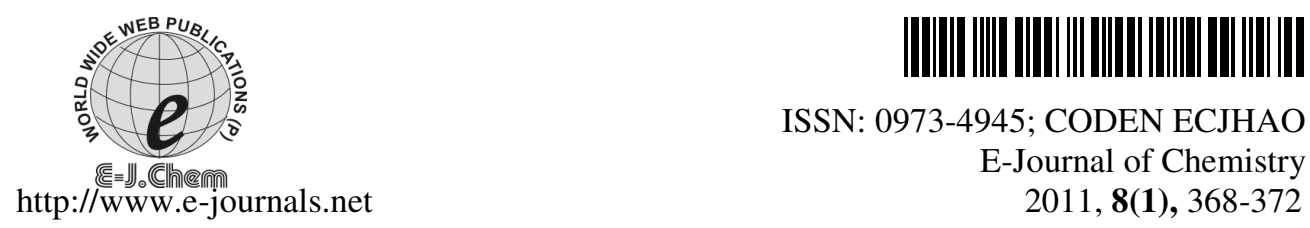

ISSN: 0973-4945; CODEN ECJHAO

E-Journal of Chemistry 2011, 8(1), 368-372

\title{
Phase Transfer Catalysis Assisted Thorpe Reaction for the Synthesis of 3-Aminothiophene-2-carboxylates
}

\author{
R D SHAH
}

\author{
Chemistry Department, M. G. Science Institute \\ Navrangpura, Ahmedabad - 380009, Gujarat, India \\ drrdshah@yahoo.co.in
}

Received 30 March 2010; Accepted 24 May 2010

\begin{abstract}
Thorpe cyclization constructing synthetically important methyl or ethyl 3-amino-4-arylthiophene-2-carboxylates has been studied using eco friendly phase transfer catalysis technique. 3-Amino-4-arylthiophene-2carboxylates have been synthesized from 3-hydroxy-2-arylacrylonitriles and thioglycolates under different solid-liquid phase-transfer conditions.
\end{abstract}

Keywords: Thorpe reaction, 3-Aminothiophenes-2-carboxylates, Thioglycolate, 3-Hydroxy-2arylacrylonitriles, Phase-transfer catalyst.

\section{Introduction}

In the chemistry of five member amino heterocycles the intermolecular Thorpe ${ }^{1-3}$ reaction and its intramolecular version Thorpe-Zeigler ${ }^{4-6}$ reactions are one of the most promising lines. They are base catalyzed and sodium or potassium alkoxide ${ }^{7,8}$, sodium hydride ${ }^{9}$, potassium hydroxide $^{10}$, lithium hydroxide ${ }^{11}$ and potassium carbonate ${ }^{1,2}$ were employed frequently. Radical alternatives ${ }^{12}$, solvent free ${ }^{13}$ strategies as well as iridium hydride complexes $^{14}$ also have been applied to intramolecular as well as intermolecular Thorpe reaction. Yet, a little to our surprise, no much attention was given to employ comprehensive strategies for Thorpe reaction involving different PT conditions.

Thorpe cyclization is well known for the formation of synthetically important five membered heterocycles such as furan, thiophene, pyrrazole and many more having adjacent amino and carbethoxy or nitrile functionalities ${ }^{1,7,15-17}$. It is very well understood that such functionalities are constructive moieties when treated with varieties of condensing agents resulting into various fused heterocycles of almost all kinds of promising biological interests $^{7,17-19}$. Strategy to incorporate Thorpe reaction with eco friendly ${ }^{15,20}$ phase-transfer catalysis (PTC) technique is always been of great interest to study. Our earlier work presented Thorpe cyclization for 3-aminopyrazole-2-carboxylates ${ }^{15}$. Herein, we report synthesis of important building blocks such as 4-substituted methyl or ethyl 3-amino-4arylthiophene-2-carboxylates involving Thorpe reaction from 3-hydroxy-2-aryl acrylonitriles $^{19}$ and thioglycolates under different solid-liquid PTC. 
Conventional method for the synthesis of methyl or ethyl 3-amino-4-arylthiophenes-2carboxylates involved the treatment of 3-hydroxy-2-arylacrylonitriles and methyl or ethyl thioglycolate with hydrochloric acid followed by sodium methoxide or ethoxide under heating condition where reaction time was $30 \mathrm{~min}$ and yield ${ }^{16,19}$ was $35-60 \%$. To set improved protocol the same reaction was assisted by PTC, where compounds methyl or ethyl 3-amino-4-arylthiophenes-2-carboxylates were synthesized from 3-hydroxy-2arylacrylonitriles, thioglycolates and $\mathrm{HCl}$ using different solid-liquid phase-transfer conditions. All reactions were carried out at RT, potassium hydroxide along with 18-crown6 was choice of catalyst, where as acetonitrile was used as solvent (Scheme 1).

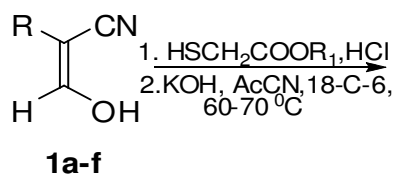<smiles>[R]c1c(CCCC(=O)OCCSC(C)=C([3H])[3H])sc(C(=O)OCC)c1N</smiles>

3a-f

\section{Scheme 1}

To optimize PT condition the same reaction was carried out using different PT catalysts in solid-liquid and liquid-liquid PTC (Table 1).

Table 1. Comparison of PTC assisted synthesis of 3-amino-4-arylthiophene-2-carboxylates (3a-f)

\begin{tabular}{|c|c|c|c|c|c|}
\hline Entry & $\mathrm{R}$ & $\mathrm{R}_{1}$ & $\begin{array}{c}\text { Liquid-liquid } \\
\text { PTC }^{\text {a }} \\
\mathrm{TBHSO}_{4} \\
\text { Yield \% }\end{array}$ & $\begin{array}{c}\text { Solid-liquid PTC } \\
\text { 18-Crown-6 } \\
\text { Yield } \%\end{array}$ & $\underset{{ }^{0} \mathrm{C}}{\mathrm{M} . \mathrm{P}}$ \\
\hline $3 \mathbf{a}^{*}$ & $\mathrm{C}_{6} \mathrm{H}_{5}$ & $\mathrm{COOCH}_{3}$ & 58 & 80 & 69 \\
\hline $3 \mathbf{b}$ & $4-\mathrm{OCH}_{3} \mathrm{CH}_{4}$ & $\mathrm{COOCH}_{3}$ & 56 & 75 & 111 \\
\hline $3 c$ & benzo[b]furyl-2 & $\mathrm{COOCH}_{3}$ & 55 & 73 & 115 \\
\hline 3d & Thienyl-2 & $\mathrm{COOCH}_{3}$ & 60 & 80 & 90 \\
\hline $3 e$ & dimethyl-2,5-thienyl & $\mathrm{COOCH}_{3}$ & 59 & 77 & 137 \\
\hline $3 f$ & $\mathrm{C}_{6} \mathrm{H}_{5}$ & $\mathrm{COOC}_{2} \mathrm{H}_{5}$ & 51 & 70 & 73 \\
\hline
\end{tabular}

Scheme 2 shows probable mechanism for Thorpe cyclization for the synthesis of 3-amino-4arylthiophene-2-carboxylates $\mathbf{3}$, in which 3-hydroxy-2-arylacrylonitriles $\mathbf{1}$ were believed to undergo reaction with thioglycolates 2 in presence of $\mathrm{HCl}$ resulting in situ generation of uncyclized thioglycolates, followed by addition of active methylene to nitrile forming compound $\mathbf{3}$.

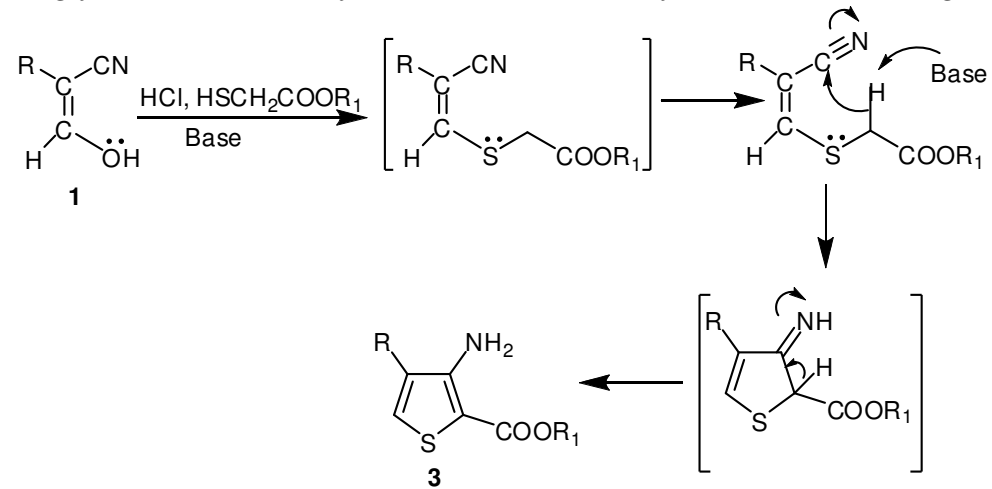

Scheme 2 
The IR spectra of 3 showed bands at $3500-3140 \mathrm{~cm}^{-1}$ for amino and $1680-1670 \mathrm{~cm}^{-1}$ for $\mathrm{C}=\mathrm{O}$ of ester functionality. Table 2 shows physical constants and ${ }^{1} \mathrm{H}$ NMR spectral data.

Table 2. Physical constants of 3-amino-4-arylthiophene-2-carboxylates (3a-f)

\begin{tabular}{|c|c|c|c|c|c|}
\hline \multirow[b]{2}{*}{ Entry } & \multirow{2}{*}{$\begin{array}{l}\text { Mol. Formula } \\
\text { (MW) }\end{array}$} & $\% \mathrm{C}$ & $\% \mathrm{H}$ & $\% \mathrm{~N}$ & \multirow[b]{2}{*}{${ }^{1} \mathrm{H}$ NMR $(\delta$ ppm $)$} \\
\hline & & $\begin{array}{l}\text { Calcd } \\
\text { (Found) }\end{array}$ & $\begin{array}{l}\text { Calcd } \\
\text { (Found) }\end{array}$ & $\begin{array}{c}\text { Calcd } \\
\text { (Found) }\end{array}$ & \\
\hline $3 \mathbf{a}^{*}$ & $\begin{array}{c}\mathrm{C}_{12} \mathrm{H}_{11} \mathrm{NO}_{2} \mathrm{~S} \\
(233.39)\end{array}$ & $\begin{array}{c}61.80 \\
(61.35)\end{array}$ & $\begin{array}{c}4.75 \\
(4.59)\end{array}$ & $\begin{array}{c}6.01 \\
(5.86)\end{array}$ & $\begin{array}{l}(\mathrm{s}, 5 \mathrm{H}, 7.0) \mathrm{Ar}-\mathrm{H} ;(\mathrm{s}, 1 \mathrm{H}, 6.75) ; \\
\mathrm{Ar}-\mathrm{H} \text { at } \mathrm{C}_{4},(\mathrm{~m}, 2 \mathrm{H}, 5.3) \mathrm{NH}_{2} ;(\mathrm{s}, \\
3 \mathrm{H}, 3.6) \mathrm{CH}_{3}\end{array}$ \\
\hline $3 b^{* *}$ & $\begin{array}{c}\mathrm{C}_{13} \mathrm{H}_{13} \mathrm{NO}_{2} \mathrm{~S} \\
(263.31)\end{array}$ & $\begin{array}{c}59.31 \\
(59.59)\end{array}$ & $\begin{array}{c}4.98 \\
(4.81)\end{array}$ & $\begin{array}{c}5.32 \\
(5.19)\end{array}$ & $\begin{array}{l}(\mathrm{d}, 2 \mathrm{H}, 7.3) \mathrm{Ar}-\mathrm{H} ;(\mathrm{d}, 2 \mathrm{H}, 6.9) \\
\mathrm{Ar}-\mathrm{H} ;(\mathrm{s}, 1 \mathrm{H}, 7.05) \mathrm{Ar}-\mathrm{H} \text { at } \mathrm{C}_{4} ; \\
(\mathrm{m}, 2 \mathrm{H}, 5.5) \mathrm{NH}_{2} ;(\mathrm{s}, 3 \mathrm{H}, 3.95) \\
\mathrm{OCH}_{3} \cdot(\mathrm{s}, 3 \mathrm{H}, 3.8) \mathrm{CH}_{3}\end{array}$ \\
\hline $3 c^{*}$ & $\begin{array}{l}\mathrm{C}_{14} \mathrm{H}_{11} \mathrm{NO}_{3} \mathrm{~S} \\
(273.31)\end{array}$ & $\begin{array}{l}61.56 \\
(61.94)\end{array}$ & $\begin{array}{l}4.06 \\
(3.91)\end{array}$ & $\begin{array}{c}5.13 \\
(4.85)\end{array}$ & $\begin{array}{l}(\mathrm{m}, 5 \mathrm{H}, 7.1-7.6) \mathrm{Ar}-\mathrm{H} ;(\mathrm{s}, 1 \mathrm{H}, \\
6.7) \mathrm{Ar}-\mathrm{H} \text { at } \mathrm{C}_{4} ;(\mathrm{m}, 2 \mathrm{H}, 6.1) \\
\mathrm{NH}_{2},(\mathrm{~s}, 3 \mathrm{H}, 3.75) \mathrm{CH}_{3}\end{array}$ \\
\hline $3 d^{*}$ & $\begin{array}{c}\mathrm{C}_{10} \mathrm{H}_{9} \mathrm{NO}_{2} \mathrm{~S}_{2} \\
(239.32)\end{array}$ & $\begin{array}{c}50.21 \\
(49.81)\end{array}$ & $\begin{array}{c}3.79 \\
(3.67)\end{array}$ & $\begin{array}{c}5.86 \\
(5.69)\end{array}$ & $\begin{array}{l}(\mathrm{m}, 4 \mathrm{H}, 6.9-7.3) \mathrm{Ar}-\mathrm{H} ;(\mathrm{m}, 2 \mathrm{H}, \\
\text { 5.7) } \mathrm{NH}_{2} ;(\mathrm{s}, 3 \mathrm{H}, 3.75) \mathrm{CH}_{3}\end{array}$ \\
\hline $3 e^{*}$ & $\begin{array}{l}\mathrm{C}_{12} \mathrm{H}_{13} \mathrm{NO}_{2} \mathrm{~S}_{2} \\
\quad(267.37)\end{array}$ & $\begin{array}{c}53.93 \\
(53.66)\end{array}$ & $\begin{array}{c}4.90 \\
(4.85)\end{array}$ & $\begin{array}{c}5.24 \\
(5.11)\end{array}$ & $\begin{array}{l}(\mathrm{s}, 1 \mathrm{H}, 6.95) \mathrm{Ar}-\mathrm{H} \text { at } \mathrm{C}_{4},(\mathrm{~s}, 1 \mathrm{H} \text {, } \\
6.5) \mathrm{Ar}-\mathrm{H} ;(\mathrm{m}, 2 \mathrm{H}, 5.5) \mathrm{NH}_{2} ;(\mathrm{s}, \\
3 \mathrm{H}, 3.75), \mathrm{CH}_{3} \text { of ester; }(\mathrm{s}, 3 \mathrm{H} \text {, } \\
2.45) \mathrm{CH}_{3} \text { at } \mathrm{C}_{2}{ }^{\prime} ;(\mathrm{s}, 3 \mathrm{H}, 2.35) \\
\mathrm{CH}_{3} \text { at } \mathrm{C}_{5} \text { ' }\end{array}$ \\
\hline $3 f^{*}$ & $\begin{array}{l}\mathrm{C}_{13} \mathrm{H}_{13} \mathrm{NO}_{2} \mathrm{~S} \\
\quad(247.07)\end{array}$ & $\begin{array}{c}63.13 \\
(63.01)\end{array}$ & $\begin{array}{c}5.30 \\
(5.34)\end{array}$ & $\begin{array}{c}5.66 \\
(5.53)\end{array}$ & $\begin{array}{l}(\mathrm{s}, 5 \mathrm{H}, 7.1) \mathrm{Ar}-\mathrm{H} ;(\mathrm{s}, 1 \mathrm{H}, 6.8) \mathrm{Ar}- \\
\mathrm{H} \text { at } \mathrm{C}_{4} ;(\mathrm{m}, 2 \mathrm{H}, 5.3) \mathrm{NH}_{2} ; \quad(\mathrm{q}, \\
2 \mathrm{H}, 4.3) \mathrm{CH}_{2} ;(\mathrm{s}, 3 \mathrm{H}, 3.6) \mathrm{CH}_{3} \text {; } \\
(\mathrm{t}, 3 \mathrm{H}, 1.29) \mathrm{CH}_{3} \text { of ester }\end{array}$ \\
\hline
\end{tabular}

Solvent used for crystallization *ethanol and **benzene:ether mixture $(5: 5)$

\section{Experimental}

Melting points were determined by electro thermal method in open capillary tube and are uncorrected. The IR spectra were recorded (in $\mathrm{cm}^{-1}$ for $\mathrm{KBr}$ pellets) on Buck-500 spectrophotometer. The ${ }^{1} \mathrm{H} \quad \mathrm{NMR}$ spectra were recorded on Bruker $300 \mathrm{MHz}$ spectrophotometer in $\mathrm{CDCl}_{3}$ using TMS as internal standard and the chemical shifts are expressed in $\delta \mathrm{ppm}$. MS spectra were recorded on JEOL/ SX-102 mass spectrophotometer under electron-impact (EI) ionization. Elemental analyses were performed on a Carlo Erba 1108 microanalyzer or Elementar's Vario EL III microanalyzer. The purity of the compounds was routinely checked by TLC using silica gel $\mathrm{G}$ and spots were exposed in iodine vapour.

General method for Synthesis of methyl or ethyl 3-amino-4-arylthiophene-2carboxylates $(3 a-f)$

\section{Method 1}

Solid-liquid PTC: A well stirred solution of toluene or MeCN $(20 \mathrm{~mL})$, powdered $\mathrm{KOH}$ (840 mg, $15 \mathrm{mmol})$ and 18-crown-6 $(0.132 \mathrm{~g}, 0.5 \mathrm{mmol})$ was added with 3-hydroxy-2arylacrylonitriles $(\mathbf{1}, 5 \mathrm{mmol})$ and thioglycolates $(2,5 \mathrm{mmol})$ and 2 drops of concentrated $\mathrm{HCl}$. Thereafter the reaction mixture was stirred for $20 \mathrm{~min}$ at room temperature $\left(35-40{ }^{\circ} \mathrm{C}\right)$. The solvent was distilled under reduced pressure and the reaction mixture was poured onto 
crushed ice, neutralized with acetic acid $(50 \% \mathrm{v} / \mathrm{v})$. The products thus obtained were filtered, washed with water, dried and crystallized from respective solvents.

\section{Method 2}

Liquid-liquid PTC: A stirred mixture of $\mathrm{CH}_{2} \mathrm{Cl}_{2}(15 \mathrm{~mL}), \mathrm{KOH}$ solution $(5 \mathrm{~mL}, 50 \% \mathrm{w} / \mathrm{v})$, and $\mathrm{TBHSO}_{4}(1.69 \mathrm{~g}, 5 \mathrm{mmol})$ was added with 3-hydroxy-2-arylacrylonitriles $(\mathbf{1}, 5 \mathrm{mmol})$ and thioglycolates $(2,5 \mathrm{mmol})$ and 2 drops of concentrated $\mathrm{HCl}$. Thereafter the reaction mixture was stirred for $20 \mathrm{~min}$ at room temperature $\left(35-40{ }^{\circ} \mathrm{C}\right)$. The solvent was distilled under reduced pressure and the reaction mixture was poured onto crushed ice, neutralized with acetic acid $(50 \% \mathrm{v} / \mathrm{v})$. The products thus obtained were filtered, washed with water, dried and crystallized from respective solvents.

\section{Results and Discussion}

In the synthesis of compound $\mathbf{3}$ there was significant improvement in the reaction time (20 $\mathrm{min}$ ), room temperature and yields (70-80\%) and the workup was clean compared to the reported methods so far ${ }^{16,19}$. However any alteration made in molar quantities of the catalyst resulted in to undesire by products and similar observation was made for the solvent.

To optimize the synthesis of compound $\mathbf{3}$, different phase-transfer catalysts and solid-liquid and liquid-liquid phase-transfer conditions were examined. For liquid-liquid phase-transfer conditions $\mathrm{CH}_{2} \mathrm{Cl}_{2} / \mathrm{KOH}$ (aq. $50 \% \mathrm{w} / \mathrm{v}$ ), low or lack of reactivity was observed in the presence of catalysts such as tetrabutylammonium bromide (TBAB) and triethylbenzyl- ammonium chloride (TEBA), results also showed concomitant decomposition of both reactants after prolonged reaction time and even under heating conditions $\left(24 \mathrm{~h}, 60-70{ }^{\circ} \mathrm{C}\right)$. Employing tricaprylmethylammonium chloride $\left(\right.$ Aliquat ${ }^{\circledR}$ ) was also unsuccessful. However, under similar conditions, tetrabutylammonium hydrogen sulfate $\left(\mathrm{TBHSO}_{4}\right)$ proved to be a better catalyst and compounds 3 were obtained in varying yields of 50-60\% (c.f. Table 1). Reducing the catalyst loading or changing the solvent resulted in a significant decrease in the yields. Increasing the temperature above $\left(50{ }^{\circ} \mathrm{C}\right)$ had little effect on the yields. Finally, in solid-liquid phase-transfer conditions the use of 18 -crown- $6, \mathrm{KOH}$ along with acetonitrile or toluene as a solvent resulted in the formation of the product 3a-f, however in acetonitrile the yields were excellent.

\section{Conclusions}

In conclusion, we have described a simple, cleaner and convenient synthesis of methyl or ethyl 3-amino-4-arylthiophene-2-carboxylates, which are important building blocks for the construction of various fused heterocycles. A comparison of conventional method, liquidliquid PTC and solid-liquid PTC suggests that the solid-liquid PTC conditions using 18-crown-6 is the method of choice with excellent yields. The ease with which phasetransfer catalyst reacts, presents new opportunities for expanding Thorpe reaction for the synthesis of other heterocycles that remains almost unexplored with PTC.

\section{Acknowledgment}

We wish to thank the Regional Sophisticated Instrumentation Center, Central Drug Research Institute, Lucknow and Chandigarh, India for ${ }^{1} \mathrm{H}$ NMR and mass spectral analysis, University Grant Commission for funding the project and Principal M. G. Science Institute, Ahmedabad for providing the facility to carry out this work.

\section{References}

1 Gewald K and Jansch H J, Calderon O DDR Patent 113,359 1975, Chem. Abstr. 1976 84, 135647. http://www.springerlink.com/content/r31475801210u360/ 
2 Gewald K and Calderon O, Monatsh Chem., 1977 108, 611.

3 Gewald K, Hain U and Hartung P, Monatsh Chem., 1981, 112, 1393.

4 Shestopalov A M, Fedorov A E and Belyakov P A, Chemistry of Heterocyclic Compounds, 2000, 36, 609.

5. Ryndina S A, Kadushkin A V, Soloveva N P and Granik V G, Russian Chemical Bulletin, 2002, 51, 854.

6. Gewald K, Schafer H, Bellmann P and Hain U, J Prakt Chem., 1992, 334, 453.

7. Dave C G, Shah A B and Shah P R Indian J Chem., 1992, 31B, 492-494.

8. Wagner G and Prantz J, Pharmazie, 1990 45, 213.

9. Kaigorodova Ye A, Vasilin V K, Konyushkin L D, Usova, Ye B and Krapivin G D, Molecules, 2000, 5, 1085.

10. Shestopalov A N, Semioshkin A A, Artemov U N, Ivanov V I, Ptashits G M and Petrovskii P V, Chem Heterocycl Compds., 1998, 34, 688.

11. Gewald K, Bellmann P and Jansch H J, Liebigs Ann Chem., 1980, 1623.

12. Curran D P and Liu W, Synlett., 1999, 117-119.

13. Yoshizawa K Toyota S and Toda S, Green Chem., 2002, 4, 68.

14. Murahashi S I, Takaya H and Naota T, Pure Appl Chem., 2002, 74, 19.

15. Desai N D and Shah R D, Synth Commun., 2008, 38, 316.

16. Kirsch G, Cagniant P and Cagniant D, J Heterocycl Chem., 1982, 19, 443.

17. Egel J, Chem Z., 1979, 103, 161.

18. Gewald K, Chimia, 1980, 34, 101.

19. Shishoo C J, Pathak U S, Jain K S, Devani I T and Chabria M T, Indian J Chem., 1994, 33B, 436.

20. Desai N D and Shah R D, Synthesis, 2006, 19, 3275. 


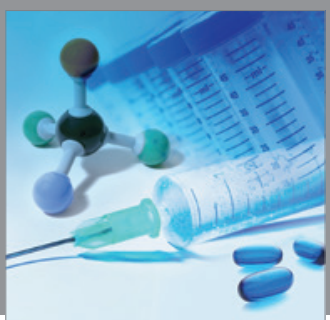

International Journal of

Medicinal Chemistry

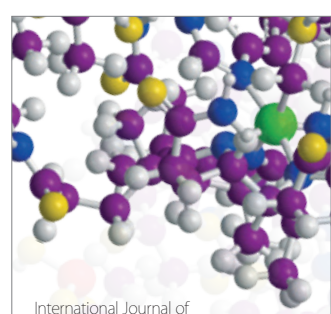

Carbohydrate Chemistry

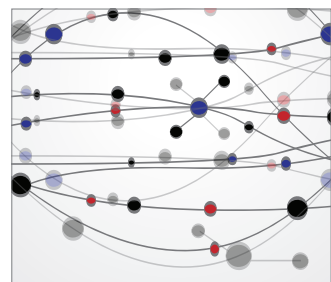

The Scientific World Journal
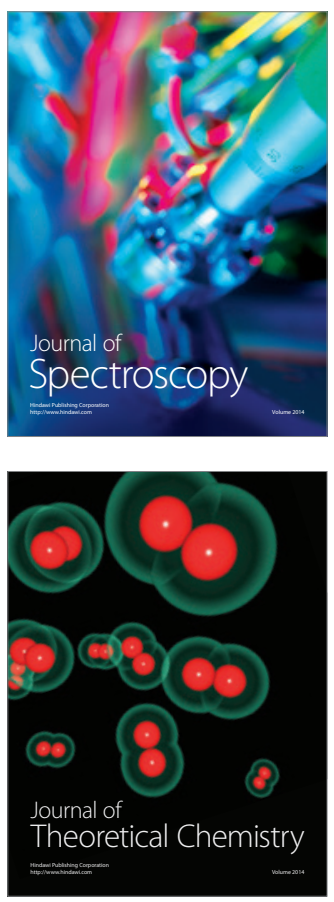
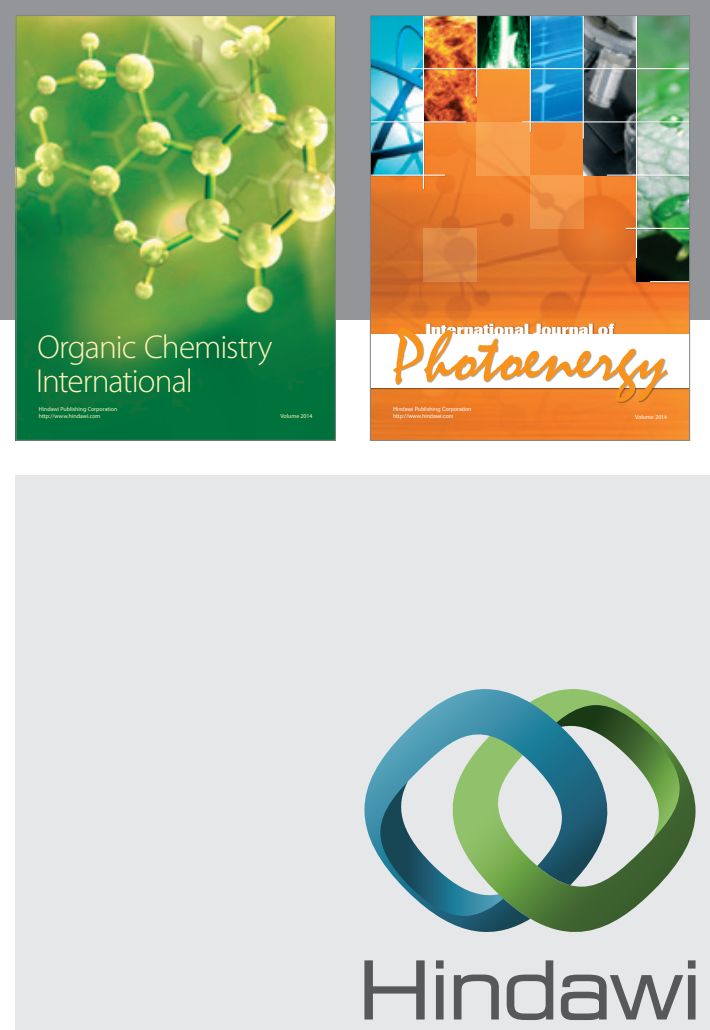

Submit your manuscripts at

http://www.hindawi.com
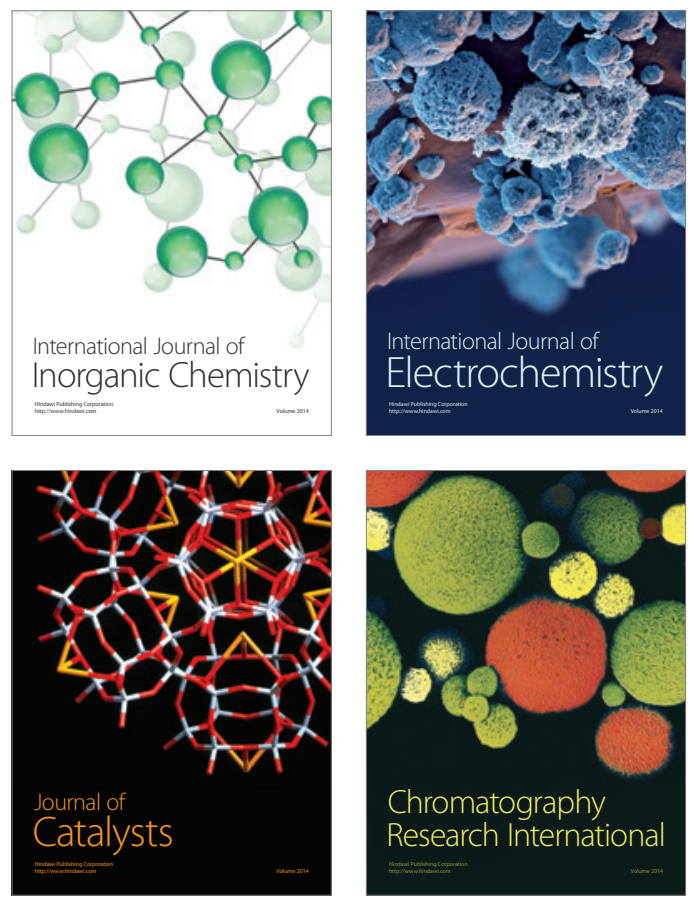
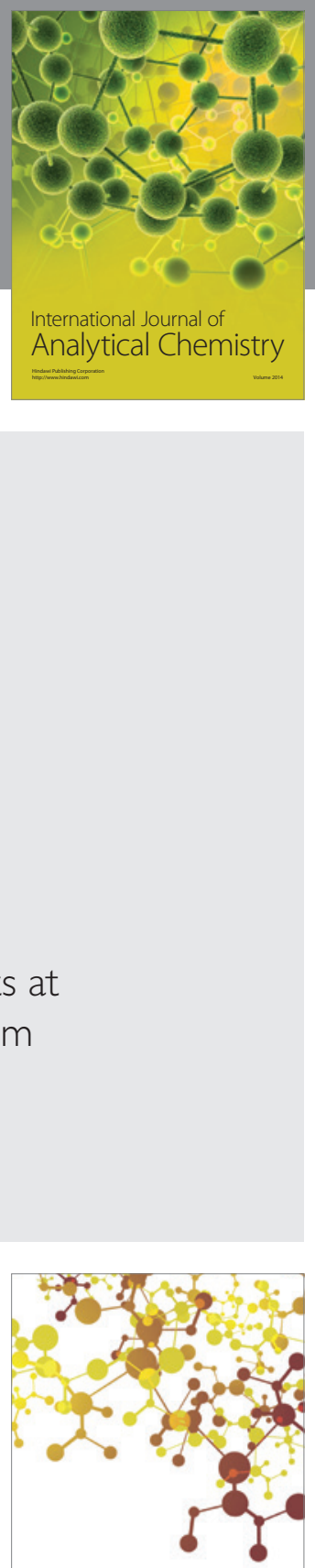

Journal of

Applied Chemistry
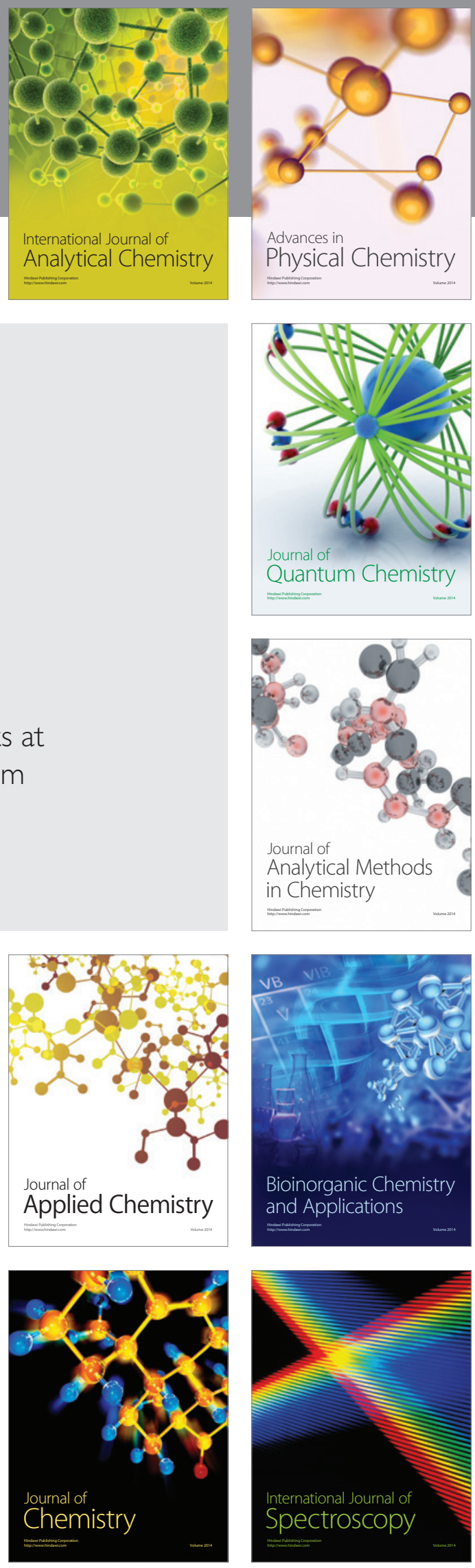